\title{
EHMTI-0037. Botulinum A toxin for treatment of chronic migraine
}

\author{
L Grazzi , S Usai, G Bussone \\ From 4th European Headache and Migraine Trust International Congress: EHMTIC 2014 \\ Copenhagen, Denmark. 18-21 September 2014
}

\section{Introduction}

Chronic migraine is a common and debilitating headache syndrome.

Botulinum neurotoxin $\mathrm{A}(\mathrm{BoNT} \mathrm{A})$, produced by the anaerobic bacterium clostridium botulinum has been recently employed for patients suffering from chronic migraine.

\section{Aims}

BoNT A has been used in our clinical experience for treating patients referring to our headache centre and suffering from chronic migraine with medication overuse.

\section{Method}

Forty four patients, suffering from chronic migraine with medication overuse, mean age $51.1+7.9$, have been submitted to a withdrawal from medications in a day hospital setting, successively they have been treated by BoNT A injection in multiple sites according to the protocol of the PREEMPT study at the dosage of $155 \mathrm{U}$ for 31 sites. Every session of local injection was repeated every three months for a period of one year.

\section{Results}

Twenty three patients achieved the 6 months follow up. The results, recorded by the diary, evidenced a significant decrease in days of headache/month (pre $20.4 \pm 6.9$ post $13.7 \pm 9.1 \mathrm{p}<0.005)$ and in medication intake/ month (pre $22.2 \pm 6.9$ post $13.8 \pm 9.2 \mathrm{p}<0.0005$ ).

\section{Conclusion}

Although these results are preliminary they led to intense efforts to evaluate analgesic properties of BoNT $\mathrm{A}$ and to assess their clinical applicability.
The pharmacological profile of BoNT A makes it a good candidate for migraine prevention as proposed in the PREEMPT study. Its long duration of action (3 months) makes it particularly attractive for patients who are not compliant with the daily use of preventive medications, or if they cannot tolerate them or when they are refractory to preventive medications.

No conflict of interest.

Published: 18 September 2014

doi:10.1186/1129-2377-15-S1-G11

Cite this article as: Grazzi et al.: EHMTI-0037. Botulinum A toxin for

treatment of chronic migraine. The Journal of Headache and Pain 201415 (Suppl 1):G11.
Submit your manuscript to a SpringerOpen ${ }^{\bullet}$ journal and benefit from:

- Convenient online submission

- Rigorous peer review

- Immediate publication on acceptance

- Open access: articles freely available online

- High visibility within the field

- Retaining the copyright to your article

Submit your next manuscript at $>$ springeropen.com 